\title{
The Role Of The Board Commissioners In The Implementation Of The Principles Of Good Corporate Governance And The Achievement Of The Performance Of Bank Perkreditan Rakyat In Tasikmalaya
}

\author{
Dedi Kusmayadi dan Iwan Hermansyah \\ Faculty of Economics, Siliwangi University, Tasikmalaya \\ Email:dieks68@yahoo.com,dieks68r@gmail.com,hermansyahiwan85@yahoo.co.id,
}

\begin{abstract}
This study aims to determine: the effect of the role of the commissioners, to the implementation of the principles of good corporate governance, the influence of the role of the commissioners and the implementation of the principles of corporate governance either partially or simultaneously on the performance of Bank Perkreditan Rakyat in Tasikmalaya. The method used a quantitative descriptive study population is a Bank Perkreditan Rakyat in Tasikmalaya, sampling using purposive sampling technique, with analysis tools using path analysis. The results showed that: the role of the board of commissioners, the implementation of the principles of corporate governance and bank performance generally categorized as good; the role of commissioner to the application of the principles of good corporate governance positively and significantly; and, the role of the commissioner and the application of the principles of good corporate governance partially and simultaneously on the performance of positive and significant influence.
\end{abstract}

Keywords: commissioners, good corporate governance, performance of the bank.

\section{INTRODUCTION}

The lack of good corporate governance is one of the triggers of the financial crisis in Asian countries (see, Johnson et al., 2000; Mitton, 2002). A key feature of poor corporate governance is selfishness on the part of corporate managers. If the manager of the company prefers the principle of self-interest and ignores the interests of the owner then in the company there will be abnormal expenditure for him so that there is a tendency of return for the owner will be reduced. Likewise, weak accountability of corporate managers, low information disclosure, and collusion, corruption, and nepotism reflect weak governance practices in both the public and private sectors (Dedi Kusmayadi, at al., 2015).

The results of ADB's (2001) study of five Asian countries, including Indonesia, which was most affected by the economic crisis, tested that poor corporate governance was one of the main causes of economic instability that ultimately affected the 1997 economic crisis. some shareholders, capital markets that are still under development, and weak legal structures are examples leading to poor corporate governance in these countries. Similarly, Johnson et al's (2000) empirical study shows that corporate governance applied within a country is better able to explain the extent of currency depreciation and declining capital market performance in developing countries than 
macroeconomics in the crisis period.

To fulfill their hopes and beliefs, the owner will appoint some people who are trusted and have the competence to represent the owner in carrying out a supervisory function that is a board of commissioner. Board of Commissioners has a very important role in the company, in addition to including in the instrument of good corporate governance, has a function to encourage the implementation of good corporate governance adequately. The ability of a company in achieving good performance cannot be separated from how the company is managed properly. Not a few companies that initially achieved good performance but because it only meets the short-term interests so that eventually the company experienced a decline and even bankruptcy.

Companies that apply the principles of good corporate governance are likely to be able to fulfill short-term and long-term interests (going concern), thus companies that have poor performance caused by poor governance, this is in line with research Gompers et al., 2003, which found the index corporate governance positively affects the company's long-term performance.

\section{LITERATURE REVIEW}

Agency theory explains that ideally, agents can be trusted to carry out their duties and responsibilities in maximizing prosperity. But in reality, agents have more information than owners, so agents will use their power to prioritize their interests over the interests of the owner (Jensen and Mecling: 1976). Agency issues not only occur between managers and owners but also between shareholders and creditors, shareholders with stakeholders such as suppliers, employees and other stakeholders (Shleiver and Vishny, 1997; Zhuang, 2000; Ariyoto, 2000). Further, Solomon and Solomon, 2004, defines corporate governance as a check and balance, both internal and external, which ensures the company performs accountability to all stakeholders. In general, good corporate governance is a system of control and corporate governance that can be seen from the mechanism of relationship between the various parties that manage the company (hard definition), as well as the value of the value contained in the mechanism of management itself (Dedi Kusmayadi et.al., 2015) .

The Board of Commissioners is the core of corporate governance assigned to oversee management in managing the company and oblige the implementation of accountability. In essence, the board of commissioners is an oversight mechanism and mechanism to provide guidance and direction to the company's management, which is the center of corporate resilience and success, meaning that the board of commissioners must be able and ensure the creation of a more objective climate, placing fairness among various interests of stakeholders. According to Effendi, 2008, several key tasks of the board of commissioners include: 1) assessing and directing corporate strategy, outlines of work plans, risk control policies, annual budgets and business plans; set work goals; overseeing the performance and performance of the company; as well as monitor the use of company capital, investment and asset sales; 2) assessing the system of paying officials in key positions and paying members of the board of directors, and ensuring a process of nominating members of the board of directors in a transparent and fair manner; 3 ) monitor 
and resolve conflicts of interest at the management level, board members and board members, including misuse of company assets and manipulation of corporate transactions; 4) monitor the implementation of governance, and make changes where necessary; and 5) monitoring the process of openness and effectiveness of communication within the company. This oversight function has received important attention from corporate governance researchers over the years, the results recommendation shows that the board of commissioners has an important role in encouraging the implementation of corporate governance and entity performance (Rindova, 1999; Boone, et al., 2007; Choi, et al ., 2007; Doidge, et al., 2007; Durnev and Kim, 2007; Fields. D, 2007; Coles, et al., 2008; Harris and Arthur, 2008; Ran, et al., 2010). While the main motivation of supervision is to believe that management operates its activities in harmony with the interests of stakeholders, especially stockholders (Rezaee, 2007).

The positioning approach of the board of commissioners as the supervisor of management/directors is based on agency theory which puts management as an 'agent' that needs to be supervised because it has opportunistic behavior. So the board of commissioners must be able to adequately guarantee that the transparency made by the management is in accordance with the existing rules and the information must be sufficient (Beekes and Brown, 2006). Disclosure and transparency can reduce uncertainty for investors and help lower capital costs. The board of commissioners plays an important role in the implementation of good corporate governance, as it is one of the most crucial internal control mechanisms authorized to make decisions on behalf of the owner. In addition, it also provides guidance and direction to corporate management (Saito and Marcos, 2006).

Corporate governance is a set of rules and procedures that ensure managers to apply ethical management principles. The Forum for Corporate Governance in Indonesia (FCGI) defines good corporate governance as a set of rules governing relationships between shareholders, managers of companies, creditor parties, governments, employees and other internal and external stakeholders related to the rights and their obligations, or in other words a system that regulates and controls the company. Corporate governance is a system, process and set of rules governing relationships between various stakeholders, especially in the narrow sense, the relationship between shareholders, the board of commissioners, and boards of directors for the achievement of organizational goals. The government strongly supports the existence of good governance system, especially on business entity owned by both state (BUMN) and region (BUMD). The Government, in this case, the Minister of State-Owned Enterprises (BUMN) in the Ministerial Regulation Number Per-01 / MBU / 2011 on the Implementation of Good Corporate Governance on State-Owned Enterprises defines good corporate governance as the underlying principles a process and mechanism of corporate governance based on legislation and business ethics. Furthermore, Corporate Governance Perception Index (CGPI) 2008, affirms good corporate governance as the structure, system, and process used by corporate organs in an effort to give the company value-added continuously in the long term, keeping the interest of other stakeholders, legislation, and prevailing norms. Likewise in Bank Indonesia Regulation Number 8/4 / PBI / 2006 dated January 30, 2006, explained that good corporate governance is a bank governance that applies the principles of transparency, accountability, responsibility, (independence) and fairness. Corporate governance is a 
corporate governance explaining the relationship between the various participants in the company that determine the direction and performance of the company (Darwis, 2009). Furthermore, Al-Ghamdi and Rhodes, 2015, state that corporate governance is a term often used to describe the processes and structures used to direct and manage the business activities of a company in order to increase shareholder wealth. Likewise, Hastori et al., 2015, argued corporate governance is the principle that directs and controls the company to achieve a balance between the strength and authority of the company in providing accountability to its shareholders in particular and stakeholders in general.

Some important things in the implementation of good corporate governance for an organization are: a) create an attraction for investors that their investment will be safe and managed efficiently, openly supported by accountable processes; b) encouraging the creation of operational competitiveness; c) enhance accountability and performance that enable confidence in organizational management; d) and improve the efficiency, effectiveness, and productivity of resource use (Dedi Kusmayadi, 2007). According to the Indonesian Banking Sector Code of good corporate governance issued by the National Committee on Corporate Governance Policy (KNKCG) in January 2006 and also through Bank Indonesia Circular Letter no. 9/12 / DPNP dated May 30, 2007, regarding the components of good corporate governance for the Bank as follows: Transparency, Accountability, Accountability, Independence, and Fairness.

Implementation of good corporate governance principles must be realized in 1) execution of duties and responsibilities of board of commissioners and directors; 2) the completeness and execution of the duties of committees and working units exercising the bank's internal control functions; 3) implementation of compliance function, internal auditor, and external auditor; 4) implementation of risk management, including internal control system; 5) provision of funds to related parties and provision of substantial funds; 6) the bank's strategic plan; and 7) transparency of bank financial and non financial condition. Some of the benefits of good corporate governance implementation are: 1) improving company performance; 2) improve corporate value; 3 ) restore investor/trust trust; 4) increasing shareholders' value and dividends (Forum Corporate Governance in Indonesia: FCGI, 2008). Implementation of good corporate governance is an important step in building market confidence and promoting a more stable, long-term international investment flows; reducing the risk level of an entity, increasing stakeholder trust, and improving performance.

The results of Black et.al., 2003, and Mitton, 2002, show good corporate governance has a significant influence on company performance. Performance is the totality of achievements achieved by the company's organization in a certain period of time. Through performance appraisal, it will be known as well as past performance and whether there is consistent improvement of performance. Besides required various sizes or standards is equally important is the existence of sufficient time span so as to be able to see better performance development (Hansen and Mowen, 2005) Performance is a difficult concept and is multidimensional, measurement system using only single measurement dimension unable to provide a comprehensive understanding (Simerly, 2000). The study of the Indonesian Institute for Corporate Governance (IICG, 2002), concludes that the main reason for good corporate governance is regulatory compliance, the company believes that the implementation of good corporate governance is another form of business ethics and 
business ethics that has long been firm commitment, corporate governance deals with improving corporate image. Klapper, 2002, found that corporate governance had a positive effect on company performance and value, and Mitton's research, 2002, found that indicators related to corporate governance had a strong impact on corporate performance. Gompers's research, et al., 2003, found a positive correlation between corporate governance index and long-term corporate performance, while Siallagan and Machfoedz, 2006, found that corporate governance mechanisms influence the firm's value. Wardhani, 2006, found that corporate governance has a positive effect on the operational performance and market performance of the company. Khomsiyah research, 2003; Darmawati et al., 2004; Dedi Kusmayadi, 2012; Mitton, 2002, found almost the same findings that good corporate governance has a positive relationship with the value/performance of the company. Black, et al., 2003, proves that corporate governance index as a whole is important and to be one of the contributing factors that can explain the market value for independent companies in Korea. Johnson, et al., 2000, concludes that the low quality of corporate governance in a country negatively impacts the stock market and exchange rates of the country concerned during times of crisis in Asia. Klapper and Love, 2003, found a positive relationship between corporate governance and company performance. Silveira and Bairos, 2006, found an influence of corporate governance quality on the market value of the company. The Dervishes research, 2009, concludes that the implementation of good corporate governance and institutional ownership has an effect on the company's performance, while the research result of Dedi Kusmayadi, et al., 2015 , shows that good governance has the positive and significant impact on satisfaction and loyalty.

Based on the theoretical and empirical studies that the author has pointed out, the hypothesis in this study is as follows:

Hypothesis 1. The role of Board of Commissioners has a positive effect on the implementation of good corporate governance principles.

Hypothesis 2. The role of Board of Commissioners and the implementation of the principle of partial and simultaneous good corporate governance have an effect on positively to bank performance.

\section{METHOD}

Objects and Subjects. Research object is something that will produce characteristics or attributes that will be the attention of researchers (Achmad, Hope: 2003). Objects in this study consist of the role of the board of commissioners, good corporate governance, and performance variables. The unit of analysis of this research is the Head Office of Bank Perkreditan Rakyat in Tasikmalaya working area of Otoritas Jasa Keuangan (OJK) Tasikmalaya.

Data Collection Method. Data type used in this research is primary data and secondary data. Primary data were collected by interview and survey methods with questionnaires related to the roles of the Board of Commissioners, Good Corporate Governance, and Performance. While the secondary data required comes from the financial statements that have been checked by the Financial Services Authority (OJK) and financial statements of the audit results of the Public Accounting Firm, as well as 
documents and other sources relevant to the study topic. All data obtained from each Head Office Bank Perkreditan Rakyat in Tasikmalaya.

Data were analyzed by using the quantitative descriptive method. This explanatory research will explain in depth the causal relationship between research variables or something (Copper, Schindler: 2005).

Population and Sample. Population in this research is All Head of Bank Perkreditan Rakyat in Tasikmalaya 2015 that is as many as 14 Bank, whereas technique of withdrawal sample uses nonprobability sampling type purposive side, with condition bank that gives complete information according to the requirement of research used as research sample. Based on the time set the number of banks that provide complete information is 12 banks (sample research).

Variable Operationalization. Variables in this research include 1) Variable board of commissioner $\left(\mathrm{X}_{1}\right)$, with research dimension, consist of (a). integrity, (b). competence and (c). independence, (d) financial reputation, 2) Variable good corporate governance $\left(\mathrm{X}_{2}\right)$, with research dimension consisting of: (a). transferase, (b). accountability, (c). responsibility, (d). fairness; 3) variable of bank performance (Y), with research dimension using CAMEL concept: (CAR, productive asset, management, earnings, and liquidity).

Research Analysis Tool. The analysis tools used include validity test and reliability test (consistency test), which aims to test the quality of the research instrument used (Uma Sekaran: 2003; Cooper, Schindler: 2005). According to Sekaran (2003), Likert has interval scale. Medium analysis tool using path analysis (path analysis).

\section{RESULTS AND DISCUSSION}

Based on the results of SPSS processing obtained the results of validity test (product moment) and reliability (Cronbach's alpha) research instrument (questionnaire) as presented in tables 1 and 2.

Tabel 1. Result of validity test of research instrument

\begin{tabular}{|c|c|c|c|c|c|c|c|}
\hline \multicolumn{3}{|c|}{ Variabel Peran Dewan Komisaris (X1) } & \multicolumn{4}{c|}{ Variabel Implementasi GCG (X2) } \\
\hline Nomor & r-hitung & r-tabel & Keterangan & Nomor & r-hitung & r-tabel & Keterangan \\
\hline \hline 1 & 0,576 & 0,9587 & valid & 1 & 0,576 & 0,7181 & Valid \\
\hline 2 & 0,576 & 0,6931 & valid & 2 & 0,576 & 0,9751 & Valid \\
\hline 3 & 0,576 & 0,7605 & valid & 3 & 0,576 & 0,6137 & Valid \\
\hline 4 & 0,576 & 0,8500 & valid & 4 & 0,576 & 0,9751 & Valid \\
\hline 5 & 0,576 & 0,6392 & valid & 5 & 0,576 & 0,9751 & Valid \\
\hline 6 & 0,576 & 0,6602 & valid & 6 & 0,576 & 0,7181 & Valid \\
\hline 7 & 0,576 & 0,6807 & valid & 7 & 0,576 & 0,6968 & Valid \\
\hline 8 & 0,576 & 0,8500 & valid & 8 & 0,576 & 0,6968 & Valid \\
\hline 9 & 0,576 & 0,7633 & valid & 9 & 0,576 & 0,9751 & Valid \\
\hline 10 & 0,576 & 0,6199 & valid & 10 & 0,576 & 0,7374 & Valid \\
\hline 11 & 0,576 & 0,6392 & valid & 11 & 0,576 & 0,7181 & Valid \\
\hline 12 & 0,576 & 0,9554 & valid & 12 & 0,576 & 0,7433 & Valid \\
\hline 13 & 0,576 & 0,7626 & valid & 13 & 0,576 & 0,5968 & Valid \\
\hline 14 & 0,576 & 0,6330 & valid & & & & \\
\hline 15 & 0,576 & 0,6802 & valid & & & & \\
\hline 16 & 0,576 & 0,6330 & valid & & & & \\
\hline
\end{tabular}

Primary data of research re-processed 
Based on Table 1 the results of validity test obtained $r$-count greater than the r-table good for board commissioner roles or variable implementation of good corporate governance. This shows that the research instrument for both variables has fulfilled the validity aspect (valid) to be used as data gathering tool.

Tabel 2. The results of the instrument research reliability test

\begin{tabular}{|c|c|c|c|c|}
\hline No & Nama Variabel & Nilai Cronbach's Alpha & Nilai Kriteria & Keterangan \\
\hline 1 & Peran Dewan Komisaris (X1) & 0.954 & 0.700 & Reliabel \\
\hline 2 & $\begin{array}{l}\text { Penerapan Good Corporate } \\
\text { Governance (X2) }\end{array}$ & 0.940 & 0.700 & Reliabel \\
\hline
\end{tabular}

Primary data of research re-processed

While Table 2 shows that the value of Cronbach's alpha is above 0.70 this indicates that the research instrument meets the reliable or consistent aspects (Uma Sekaran: 2003). Thus the research instrument meets the validity and reliability aspects worthy to be instrumental in the research.

Furthermore from the results of data collection of commissioner role roles obtained the total number of respondents answer reply 886, indicating in interval class including good predicate category. This means that the role of the board of commissioners plays an important role and has contributed positively in encouraging the implementation of good corporate governance principles and achievement of performance in Bank Perkreditan Rakyat in Tasikmalaya region. However, based on the recapitulation of the responses of respondents, it should be noted that there are still some items concerning the role of boards that need to be optimized in strengthening its role in Bank Perkreditan Rakyat in Tasikmalaya region, the role of real in achieving company goals, support for strengthening roles in addition to banking companions, the relevance of experience, financial reputation and independence (related relationship).

While the recapitulation for the implementation variable of Good Corporate Governance is obtained the total score of respondent reply 774. The value is in good predicate interval, it implies that the implementation of the principle of Good corporate governance at Bank Perkreditan Rakyat has been implemented with reference to the regulation determined in addition to having a position which is very important in realizing the performance of Bank Perkreditan Rakyat in Tasikmalaya Region. On the performance variable of Bank Perkreditan Rakyat in Tasikmalaya region using CAMEL concept (Capital Adequacy Ratio, Assets, Management, Earnings, and Liquidity), as shown in Figure 1 and Figure 2.

Capital Adequacy Ratio (CAR) is a capital adequacy ratio that serves to accommodate the risk of losses that may be faced by banks. Capital Adequacy Ratio shows how far all bank assets that contain risk (credits, investments, securities, bills with other banks) participate in financing from bank's own capital funds in addition to obtaining funds from sources outside the bank, such as funds from the community, loans, and others. 


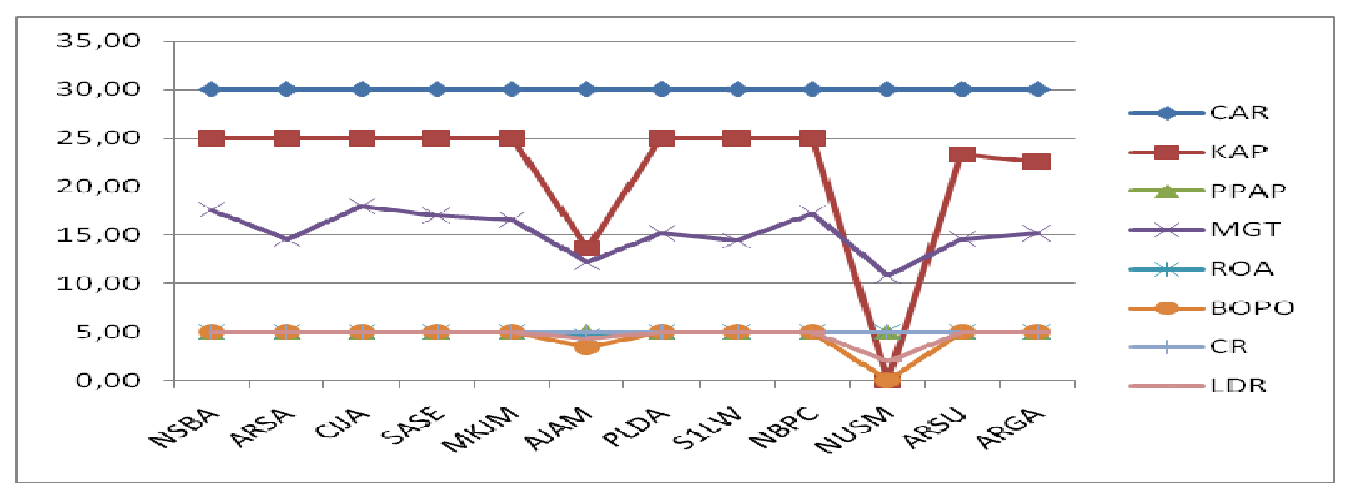

(Primary data of research re-processed; Otoritas Jasa Keuangan 2015)

Gambar 1. CAMEL Bank Perkreditan Rakyat Credit Ratio in Tasikmalaya Region Year 2015

Capital Adequacy Ratio (CAR) is an indicator of the bank's ability to cover its decline in assets as a result of bank losses caused by risky assets. Based on the provisions of Bank Indonesia minimum CAR must reach $8 \%$, if the capital adequacy ratio of a bank below $8 \%$ then the bank does not have sufficient capital and including unhealthy predicate. Based on the results of research from 12 (twelve) Bank Perkreditan Rakyat located in the Tasikmalaya region shows that the capital adequacy ratio of Peripheral Banks in Tasikmalaya is above $8 \%$, this means that in terms of capital adequacy ratio aspect, category able to meet the capital adequacy and enter into the category of healthy predicate.

Bank assets consist of earning assets and non earning assets. A productive asset is an income-generating asset. The earning asset is a placement of bank funds in foreign currency in the form of credit, securities, fund placements between banks, investments, including commitments and contingencies on off-balance sheet transactions. Nonproductive assets are non-income earning assets. The quality of Earning Assets is earnings asset quality that is the benchmark for assessing the likelihood level of the receipt of funds invested in earning assets (principal including interest) based on certain criteria; in Indonesia, the quality of earning assets is assessed on the basis of its collectability, ie current, noncurrent credit, doubtful credit, or non-performing loans. Based on the result of the research, it can be seen from the aspect of Earning Asset Quality of ten banks or $83.33 \%$ (at the value of ratio $<1035$ ) including healthy predicate category, while one bank or $8.33 \%$ belong to the category of unhealthy predicate (at ratio value $>12.60-14.85$ ), and one bank or $8.33 \%$ including unhealthy predicate category (in the ratio value $>14.85$ ).

Productive assets serve to earn income on funds disbursed by banks. However, placement of funds in earning assets also has a risk, ie the risk of funds disbursed cannot be returned. The risk of placement in this form may result in bank losses. Banks need to establish the provision for losses on earning assets, ie allowance for uncollectible accounts (PPAP). Thus, the allowance for uncollectible accounts entered into this account is an allowance established to cover possible losses arising from the non-acceptable part or all of the loans or funds established in other banks, as provided for in the provisions of Bank Indonesia concerning allowance for uncollectible accounts (PPAP). Allowance for 
possible losses on Assets (PPAP) reserves that must be established for a certain percentage of the outstanding balance based on the classification of the quality of earning assets as stipulated in Bank Indonesia regulations. The result of the research shows that the aspect of Allowance for Earning Assets Losses of 12 (twelve) Bank Perkreditan Rakyat in Tasikmalaya region is included in the category of the healthy predicate, meaning that the bank has fulfilled the aspect of the obligation to make the PPAP as required with the ratio $>81$.

Management or management of a bank will decide whether or not a bank healthy. Considering that, the management of a management a great concern in the assessment of the soundness of a bank is expected to create and maintain its health. The assessment of management factors in the assessment of bank soundness is done by evaluating the management of the bank concerned which is grouped into two groups general management. risk management, risk management, and risk management. Based on the results of the research indicates that from the management aspect, six banks or $50 \%$, Bank Perkreditan Rakyat in Tasikmalaya region are in the category of healthy predicate, four banks or $33.33 \%$ of banks are healthy predicate (in the ratio of 66-81), and two banks or $16.66 \%$ of banks are in the category of less healthy predicate. From the aspect of the management of Bank Perkreditan Rakyat in the Tasikmalaya region still needs to be done hard to make improvements in general management and risk management.

Return on Assets is one of the profitability ratios. Return on Assets is used to measure management effectiveness in generating profits with available assets, the higher the return on the firm's total assets the better the company's performance (Gitman and Zutter, 2015). In the analysis of financial statements, this ratio is most often highlighted, because it is able to show the success of the company generate profits. ROA is able to measure the ability of the company to generate profits in the past to then be projected in the future. The asset or power which is the total assets of the enterprise, derived from the capital itself or from the capital that has been converted into a company's capital goods used for the relationship of life of the company. Viewed from the aspect of Return on Assets (ROA), shows that Bank Perkreditan Rakyat in Tasikmalaya region can create profit (profit), 12 (twelve) Bank Perkreditan Rakyat in Tasikmalaya region are a healthy category (in a ratio $>1,215$ )

BOPO is a ratio group that measures efficiency and operational efficiency with others. The ratio of operating costs is. Operational cost ratio for. The lower BOPO means the more efficient the bank is in its operational costs, with the cost efficiency, the greater the bank profit. BOPO shows that the operation of Bank Perkreditan Rakyat in the Tasikmalaya region is generally under control so that the bank's management is good enough in controlling the bank's operational costs. From 12 (twelve) banks studied showed eleven banks or $91.66 \%$ including healthy category (in ratio $<93,60$ ), and one bank or $8.33 \%$ including healthy predicate category (at ratio $>93,60-94.80$ ).

Cash Ratio is the ratio used to measure the ability of banks in repaying customer deposits when withdrawn by using liquid tool possessed. Under the terms of Bank Indonesia, the liquid instrument consists of cash plus bank accounts deposited at Bank Indonesia. The higher the value of the cash ratio the higher the bank's liquidity capability is concerned, but in practice, it will affect its productivity. The results show that in general, Bank Perkreditan Rakyat in Tasikmalaya are able to control the liquidity aspect or 
have sufficient capability in fulfilling their short-term debts. Based on the results of research shows that viewed from the cash ratio of 12 (twelve) Bank Perkreditan Rakyat in the Tasikmalaya region has a level of liquidity including healthy category (in the ratio value $>4.05-5.00)$.

Loan to Deposit Ratio (LDR) is The ratio between the total amount of credit granted by the bank and the funds received by the bank. This ratio indicates one of the bank's liquidity rating. The higher the ratio gives an indication of the lower the bank's liquidity capability. Based on the results of research shows that viewed from the LDR as many as 11 banks or $91.66 \%$, Bank Perkreditan Rakyat in the region Tasikmalaya including healthy predicate category (in the value ratio $<94.75$ ), while one bank or $8.33 \%$ including unhealthy predicate category (above $>102$ ). Based on the above data, each CAMEL component (capital, asset, management, earning and liquidity) ratio value into factor credit that reflects the achievement value of the bank's health performance as shown in Figure 2.

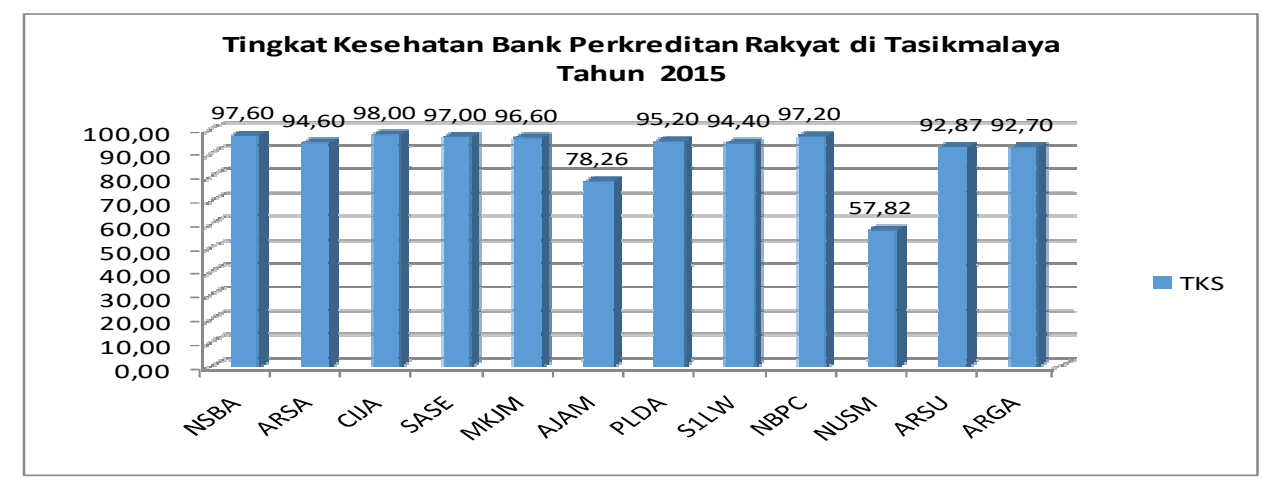

(Primary data of research re-processed; Otoritas Jasa Keuangan 2015)

Figure 2. Health Level (CAMEL) of Bank Perkreditan Rakyat in the Tasikmalaya region in 2015

Based on figure 2, it shows that the level of health with factor value using CAMEL analysis is obtained by ten banks or $83.33 \%$ including healthy predicate category (in position value ratio $>81$ ), while one bank or $8.33 \%$ are in fairly healthy predicate category (in position value ratio 66-> 81), and one bank or $8.33 \%$ including unhealthy predicate category (at the value of ratio $<61$ ).

Based on the data analysis, the results obtained to answer the hypothesis as presented in table 3 and Table 4.

Tabel 3. Recapitulation of the influence of the role of the Board of Commissioners on the implementation of Good Corporate Governance principles

\begin{tabular}{|c|c|c|c|}
\hline No & Uraian & Hasil & Keterangan \\
\hline \hline 1 & R & 0.665 & \\
\hline 2 & R Square & 0.442 & \\
\hline 3 & F-hitung & 7.919 & Signifikan \\
\hline 4 & Sig (F) & & Signifikan \\
\hline
\end{tabular}


Tabel 4. Recapitulation of the role analysis of the Board of Commissioners and implementation of Good Corporate Governance on performance

\begin{tabular}{|c|c|c|c|}
\hline No & Uraian & Hasil & Keterangan \\
\hline \hline 1 & R & 0.984 & \\
\hline 2 & R Square & 0.987 & \\
\hline 3 & F-hitung & 133.074 & Signifikan \\
\hline 4 & Beta (X1) & 0.611 & \\
\hline 5 & Beta (X2) & 0.465 & \\
\hline 6 & t-hitung (X1) & 7.567 & Signifikan \\
\hline 7 & t-hitung (X2) & 5.766 & Signifikan \\
\hline 8 & Sig (X1) & 0.000 & Signifikan \\
\hline 9 & Sig (X2 & 0.000 & Signifikan \\
\hline 10 & Sig F & 0.000 & Signifikan \\
\hline
\end{tabular}

Furthermore from Table 3 and tab 4 can be visualized in the complete path diagram presented in figure 3.

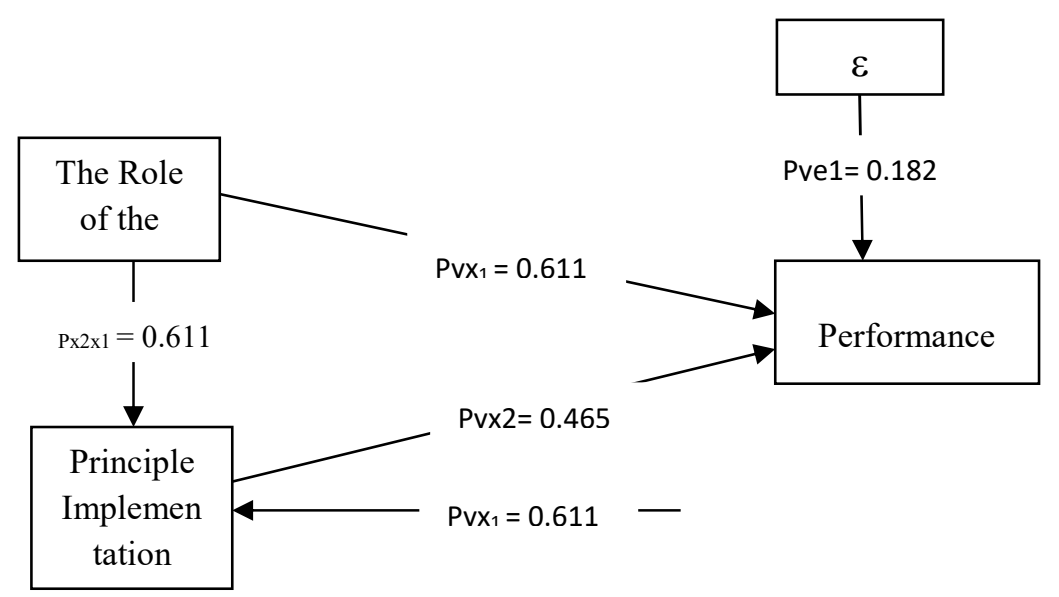

Figure 3. Structure Influence variable Role Board of Commissioners and Variable Implementation Principles of good corporate governance to Performance

\section{Hypothesis 1: The Influence of Role of Board of Commissioners on Implementation of Good Corporate Governance Principle In BPR Tasikmalaya}

Referring to the result of analysis of the influence of the role of the board of commissioner toward the implementation of good corporate governance principle (table 3 ), obtained the beta coefficient of $66.5 \%$. This shows that the implementation of good corporate governance principles in Bank Perkreditan Rakyat in Tasikmalaya region is influenced by the role of the board of commissioners of $44.2 \%$. While $55.8 \%$ influenced by other factors such as the competence of human resources, work culture, organizational culture, and other factors

Hypothesis testing can be seen from the significance value of 0.018 is smaller than the specified critical value (alpha) of 0.05 , it means the hypothesis proposed that the role of the board of commissioner has a positive effect on the implementation of good corporate governance principles in Bank Perkreditan Rakyat in Tasikmalaya region tested. This provides an indication of the more adequate and optimal role of the board of 
commissioners will have an impact on the better and optimal implementation of good corporate governance principles in Bank Perkreditan Rakyat in Tasikmalaya region.

Corporate Governance contains the principles of corporate management with due consideration of the balance of the implementing authority of the company with the interests of shareholders as well as the interests of the wider community as part of the stakeholders. Internally, the balance of the authority of directors and commissioners and shareholder rights is structured in such a way through the principles of corporate governance and the institutional structure of the company can move in the interests of shareholders and the general public. The role of commissioners is necessary to oversee the operation of the company by ensuring that the company has conducted transparency, accountability, independence and justice practices in accordance with the prevailing provisions of an economic system. Good corporate governance is a linkage between the company's stakeholders used to establish and oversee the strategic direction and performance of an organization's business.

With these findings visible, the strategic role of the board of commissioners in exercising control, supervision and consultative activities proactively in the achievement of the established objectives refers to good corporate governance practices, including 1) assessing and directing corporate strategy, outlines of work plans, policies risk control, annual budget, and business plan; set work goals; overseeing the performance and performance of the company; as well as monitor the use of company capital, investment and asset sales; 2) assessing the system of paying officials in key positions and paying members of the board of directors, and ensuring a process of nominating members of the board of directors in a transparent and fair manner; 3) monitor and resolve conflicts of interest at the management level, board members and board members, including misuse of company assets and manipulation of corporate transactions; 4) monitor the implementation of governance, and make changes where necessary; 5) monitor the process of openness and effectiveness of communication within the company. The findings of this study are consistent and consistent with previous concepts and research including research by Rindova, 1999; Boone, et al., 2007; Choi, et al., 2007; Doidge at al., 2007; Fields, 2007; Dedi Kusmayadi; 2007; Coles, et al., 2008, Harris and Arthur, 2008; Ran, et al., 2010).

\section{Hypothesis 2: Partial and simultaneous Influence Board of Commissioners' Roles and Implementation of Good Corporate Governance Principles on Bank Perkreditan Rakyat Performance in Tasikmalaya Region}

The result of data processing shows that the coefficient of the board of commissioner's role to the financial performance is 0.611 , or in other words, the direct influence of the board of commissioner's role to the financial performance is $37.33 \%$. While the indirect influence through the implementation of the principle of good corporate governance is $37.79 \%$, thus the total influence of the board of commissioners role to the performance of $75.12 \%$. Indirect effects appear larger than indirect influences although they have a material contribution to the overall effect. This provides an indication that the role of the board of commissioners should be more effective in carrying out its responsibilities, especially in the process of achieving performance, including in optimally promoting the implementation of the principle of good corporate governance. Significant value obtained by 0.00 is smaller than the critical standard (alpha) which is set at $5 \%$, 
meaning the hypothesis proposed that the role of the board of commissioner has a positive effect on the performance tested. This indicates that adequate role of the board of commissioner will give impact to the better performance of Bank Perkreditan Rakyat in Tasikmalaya region, in other words, the optimal role of a board of commissioner will provide optimal synergy both in process level and in final achievement of the operational process of performance achievement. The work program, supervisory system, controlling, review system, consultative function, professional and follow up are instruments that need to be followed and implemented adequately so that the overall role of board of commissioners as a function of institutional control representing the owner will be adequate in the effort to believe the board of directors has been able to carry out their responsibilities effective and efficient as well as professional. The results of this study are relevant to the concept and some previous studies of Rindova, 1999; Boone et al., 2007; Choi et al., 2007; Doidge et al., 2007; Durnev and Fields, 2007; Coles et al., 2008; Harris, Arthur, 2008; Ran, et al., 2010; Rezaee, 2007.

The result of data processing shows that the coefficient of implementation path of good corporate governance toward financial performance is $46.5 \%$, or in other words, the effect of direct implementation of good corporate governance principles to financial performance amounted to $21.62 \%$. The significance value obtained is 0.00 less than the critical standard (alpha) is set at 5\%, meaning that the hypothesis proposed that the implementation of good corporate governance principles have a positive effect on the performance tested. This shows that the implementation of a good and adequate strategy will have an impact on the better performance of Bank Perkreditan Rakyat in the Tasikmalaya region so that the more optimal implementation of good corporate governance principles will provide optimal synergies both in the process level and in the final achievement of the operational process performance achievement. Implementation of guarantees, accountability, responsibility, independence, and fairness are key factors for an entity in building a healthy order and achieving goals in accordance with established vision and mission. Supporting the role of commissioners is very important in the process of implementing the principles of good corporate governance because the role of the board of commissioners is one of the key success factors for an entity in the implementation properly and adequately. Implementation of good corporate governance principles must be realized in 1) execution of duties and responsibilities of board of commissioners and directors; 2) the completeness and execution of the duties of committees and working units exercising the bank's internal control functions; 3) implementation of compliance function, internal auditor, and external auditor; 4) implementation of risk management, including internal control system; 5) provision of funds to related parties and provision of substantial funds; 6) the bank's strategic plan; and 7) transparency of bank financial and non financial condition. There are several benefits of good corporate governance implementation, among others: 1) improving company performance; 2) improve corporate value; 3) restore investor/trust trust; 4) increase shareholders' value and dividends. The results of this study are relevant to the concept and some previous research which generally found that good corporate governance has positive effect on the improvement of image, company value, performance and achievement of the objectives of research from Darwin, 2009; Dedi Kusmayadi, et al., 2015; Research The Indonesian Institute for Corporate Governance (IICG): 2002, Klapper, 2000, Gompers, et al., 2003, Siallagan and 
Machfoedz., 2006; Wardhani, 2006; Khomsiyah, 2003; Darmawati et.al., 2004; Dedi Kusmayadi, 2012; Mitton, 2002; Black, et al., 2003; Klapper and Love, 2003.

While the influence simultaneously the role of the board of commissioner and the implementation of good corporate governance principles to the performance of $96.7 \%$, and the rest of $3.33 \%$ is the residual variable factor that is suspected, among others, the competence of human resources, level of competition, regulation and other factors. The result of significance test shows that the significance value of $F$ obtained is 0.00 is smaller than the critical standard (alpha) which is set at 5\%. This indicates that the hypothesis proposed by the board of commissioner and the implementation of the principle of good corporate governance have a positive effect on the performance of Bank Perkreditan Rakyat in the Tasikmalaya region tested (acceptable research hypothesis). Looking at all the path coefficients shows a positive notation with significant influence, the results provide a strong indication that the role of the board of commissioners and the implementation of the principle of good corporate governance is an important element in contributing to the achievement of the performance of Bank Perkreditan Rakyat in Tasikmalaya region.

The Board of Commissioners as a control function represents the owner's professional attitude to obtain reasonable assurance that the operation including the implementation of good corporate governance principles has been implemented properly and adequately. The better and optimal role of the board of commissioners is run beside will strengthen the realization of the implementation of the principles of good corporate governance either directly or indirectly will give a better impact also the achievement of the performance of Bank Perkreditan Rakyat in Tasikmalaya region. When viewed from the total influence of the board of commissioner's role on the performance appear larger than the influence of the implementation of good corporate governance principles on performance, this gives an indication that the role of board of commissioners is very important and have a strong impact both in realizing the implementation of good corporate governance principles and in achieving the performance at the Bank Perkreditan Rakyat in the Tasikmalaya region. Thus, considering the position of the board of commissioners is very strategic in a company, the board of commissioners must meet the requirements of integrity, competence, good financial reputation and independent. So that existence gives positive synergy in achieving company goal. The findings of this study reinforce and align with the previous concepts and research of Dedi Kusmayadi, 2007; Darwin, 2009, Dedi Kusmayadi, et al., 2015; IICG, 2002; Klapper, 2002; Gompers, et al., 2003; Siallagan and Machfoedz, 2006, Wardhani, 2006; Khomsiyah, 2003; Darmawati, et.al., 2004; Dedi Kusmayadi, 2012; Mitton, 2002; Black, et al ,. 2003; Klapper and Love, 2003; Rindova, 1999; Boone et al., 2007; Choi et al., 2007; Doidge at al., 2007; Fields., 2007; Coles et al., 2008; Harris and Arthur, 2008; Ran et al., 2010.

\section{CONCLUSION}

The role of the board of commissioners has a positive and significant impact on the implementation of good corporate governance, so the more optimal the role of the board of commissioners will give better impact and effective implementation of good corporate governance principles in Bank Perkreditan Rakyat in Tasikmalaya region. 
The role of the board of commissioners and the implementation of the principles of good corporate governance partially or simultaneously have a positive and significant impact on the performance of Bank Perkreditan Rakyat in Tasikmalaya region. The influence of the board of commissioner's role on performance is greater than the influence of the implementation of good corporate governance principles in Bank Perkreditan Rakyat in Tasikmalaya.

\section{REFERENCES}

Achmad Bachrudin, Harapan L. Tobing. (2003). Analisis Data Untuk Penelitian Survei Dengan Menggunakan Lisrel 8, FMIPA, Unpad Bandung.

Al-Ghamdi, Mohammed dan Rhodes, Mark. (2015). "Family Ownership, Corporate Governance and Performance: Evidence from Saudi Arabia". International Journal of Economics and Finance. 7 (2).

Ariyoto, Archon, Fung and Erik Olin Wright. (2000). Deepening Democracy: Institutional Innovations in Empowered Participatory Governance, The Real Utopias Project IV, London: Verso

Asian Development Bank. (2001). Governance: Sound Development Management.

Bank Indonesia. (2007). Surat Edaran BI No 9/12/DPNP tanggal 30 Mei 2007 tentang Perihal Pelaksanaan Good Corporate Governance Bagi Bank Umum

Bank Indonesia. (1998). Surat Keputusan Direksi Bank No.30/277/KEP/DIR tanggal 19 Maret 1998 tentang Cara Penilaian Tingkat Kesehatan Bank

Black, B.S., Jang, H., \& Kim, W. (2003). Predicting Firms Corporate Governance Choices:EvidencefromKorea.WorkingPaper.http://papers.ssrn.com/abstract=428662.

Beekes, W. \& Brown, P. (2006). "Do Better-governed Austra-lian Firms Make More Informative Disclosures", Journal of Business, Finance and Accounting, 33(3-4), 422-50.

Boone, A., Field, L.C., Karpoff, J.M. \& Reheja, C.G. (2007). "The Determinants of Corporate Board Size and Composition: An Empirical Analysis." Journal of Financial Economics, 85, 66-101

Choi, J. J., Sae, W. P., and Sean, S.Y. (2007). "The Value of Outside Directors: Evidence from Corporate Governance Reform from Korea". Journal of Financial and Quantitative Analysis, 42 (4).

Coles, J.L., Daniel, N.D., \& Naveen, L. (2008). “Boards: DoesOne Size Fit All?”, Journal of Financial Economics, 87(2), 329-356.

Cooper, Donald R, Pamela S. Schindler. (2005). Business Research Methodes. $7^{\text {th }}$ Edition, McGraw-Hill Interrnational Edition, Boston

Corporate Governance Perception Index. (2008). Good Corporate Governance dalam persfektif Manajemen Stratejik. Jakarta: The Indonesian Institute for Corporate Governance.

Darmawati, Deni, Khomsiyah, dan Rika Gelar Rahayu. (2005). "Hubungan Corporate Governance dan Kinerja Perusahaan", Jurnal Riset Akuntansi Indonesia, 8 (1), Edisi Januari.

Darwis, H. (2009). "Corporate Governance terhadap Kinerja Perusahaan". Jurnal Keuangan Perbankan, 13(3), 418-430 
Dedi Kusmayadi, Jajang Badruzaman, Dedi Rudiana. (2015). "Pemodelan tatakelola yang baik Pasca Rintisan Sekolah Bertarap Internasional (RSBI)", Jurnal Magister Manajemen, ISSN No. 2085-7055, 8 (2), Program Pascasarjana Universitas Siliwangi

. (2015). Good Corporate Governance, Cetakan Pertama , ISBN 978602 718961 4, Penerbit LPPM Universitas Siliwangi

Dedi Kusmayadi. (2007). "Esensi Good Corporate Governance: Dalam Persfektif Kajian Teoritis", Jurnal Akuntansi, ISSN No. 1907-9958, 2 (1). Januari -Juli 2, Jurusan Akuntansi Fakultas Ekonomi, Universitas Siliwangi

. (2012). "Determinasi Audit Internal dalam Mewujudkan Good Corporate Governance serta Implikasinya pada kinerja bank", Jurkubang, ISSN 1410-8089, SK N0 64a/DIKTI/kep/2010, 16 (2), Universitas Merdeka Malang

Doidge, C., Karolyi, G.A., \& Stulz, R.M. (2007). "Why Do Countries Matter So Much for Corporate Governance." Journal of Financial Economics, 86: 1-39.

Durnev, A. \& Kim, E.H (2007). "Explaining Differences inthe Quality of Governance among Companies: Evidence from Emerging Markets". Journal of Applied Corporate Finance, 19: 29-37.

Effendi, Muh. Arief (2008) The Power of GoodCorporate Governance Teori danIplementasi. Jakarta: Salemba Empat.

Fields, D. (2007). "Governance in Permanent Whitewater:The Board's Role in Planning and Implementing Organizational Change. Corporate Governance: An International View, 15(2), 334-344.

Gitman, Lawrence J, and Zutter, Chad J., (2015). Priciples of Managerial Finance. 15th Edition Edinburgh: Pearson

Gompers,P.A, Ishii,J.L \& Metrict, (2003). Corporate Governance and Equity Prices. Working Paper (August)

Hansen. Don, R, Maryanne M. Mowen. (2005). "Management Accounting, South Western, Internalational Thompson Publishing

Harris, M. \& Arthur, R. (2008). "A Theory of Board Control and Size". Review of Financial Studies, 21(4), 1797-1832.

Haryani, Linggar Pratiwi, dan Muchamad Syafruddin, (2011). "Pengaruh Mekanisme Corporate Governance terhadap Kinerja: Transparansi sebagai Variabel Intervening", Dipresentasikan pada Simposium Nasional Akuntansi XIV Aceh.

Hastori., Siregar, Hermanto., Sembel, Roy., Maulana.Tb.N.Ahmad. (2015) "Tata Kelola, Konsentrasi Saham dan Kinerja Perusahaan Agroindustri Indonesia". Jurnal Manajemen Teknologi. 14 (2), 4-8.

Jensen, Michael C. dan W.H. Meckling, (1976). "Theory of The Firm: Managerial Behavior, Agency Cost and Ownership Structure". Journal of Financial Economics, 3: 305-360.

Johnson, Simon; P. Boone; A. Breach; dan E. Friedman, (2000). "Corporate governance in Asian financial crisis". Journal of Financial Economics, 58: 141-186.

Klapper, Leora F., and I. Love, (2002). Corporate Governance, Investor Protection, and Performance in Emerging Markets. World Bank Working Paper, http://ssrn.com, diakses tanggal 20 Februari 2013. 
Klapper, Leora F. and I. Love, (2003). Corporate governance, investor protection, and performance in emerging markets. World Bank Working Paper.http:// ssrn.com

Khomsiyah, (2003). "Hubungan Corporate Governance dan Pengungkapan Informasi: Pengujian Simultan”. Makalah, SNA VI.

Komite Nasional Kebijakan Corporate Governance, (2007). Pedoman Good Corporate Governance Perbankan Indonesia. Jakarta: KNKCG 2007.

Mitton, T, (2002). "A Cross-firm Analysis of The Impact of Corporate Governance on the Easr Asian Financial Crisis", Journal of Financial Economics, 64 (2), 215-241

Peraturan Menteri Nomor, (2011). Per-01/MBU/2011 tentang Penerapan Tata Kelola Perusahaan yang Baik (Good Corporate Governance) pada Badan Usaha Milik Negara

Peraturan Bank Indonesia, (2006) Nomor 8/4/PBI/2006 Tanggal 30 Januari 2006, Tentang Pelaksanaan Good Corporate Governance Bagi Bank Umum.

Peraturan Bank Indonesia, (2012) Nomor 14/9/PBI/2012, Tentang Uji Kemampuan dan Kepatutan (fit and proper test) Bank Perkreditan Rakyat.

Ran, D., Matsusaka, J. \& Ozbas, O. (2010) When Are Outside Directors Effective? Journal of Financial Economics, 96: 195-214.

Rindova, V., (1999). "What Corporate Boards Have to Do with Strategy: A Cognitive Perspective". Journal of Management Studies, 36: 953-977.

Rezaee, Z., (2007). Corporate Governance Post-Sarbanes-Oxley John Wiley \& Sons, Inc.

Saito, R. \& Marcos, G.L.D., (2006). "Boards of Directors of Publicly-Held Companies in Brazil: Profile and Implications for Minority Shareholders. Corporate Governance: An International View, 14(20), 98-106.

Simerly. R. L, Li, Mingfang, (2000). "Environmental Dinamism, Capital Structure and Performance: A Theoritical Integration and An Empirical Test", Strategic Management Journal, 21 (1), 31-49.

Shleiver, A. dan R.W. Vishny, (1997). "A survey of corporate governance". Journal of Finance, 52, 737-783.

Siallagan \& Machfoedz, M., (2006). Mekanisme Corporate Governance, KualitasLaba dan Nilai Perusahaan. Makalah SNA IX.

Solomon, J and Solomon A, (2004). Corporate Governance and Accountability, England, John Willey \& Son, Ltd.

Uma Sekaran., (2003). Research Methode For Business: Askill Building Approach, John Wiley \& Sons.

Undang-undang Nomor 10 Tahun 1998, Tentang Perubahan Atas Undang-undang Nomor 7 Tahun 1992 tentang Perbankan.

Wardhani, R. (2006). "Mekanisme Corporate Governance dalam Perusahaan yang Mengalami Permasalahan Keuangan (Financially Distressed Firms)". Makalah SNA $I X$.

Zhuang, (2000) Corporate Governance and Finace in East Asia: A Study of Indonesia, Republik of Korea, Malaysia, Philippines, and Thailand, Asian Development Bank 